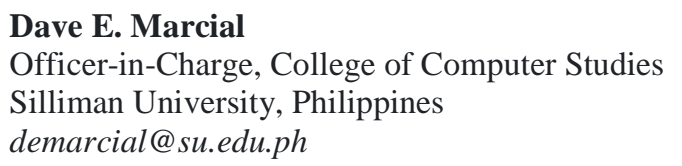

Rey Dennis B. Caballero

Cyberlibrary Supervisor

Silliman University, Philippines

reybcaballero@su.edu.ph

Jeambe B. Rendal

Student, Master in Information Systems, University Graduate Programs

Silliman University, Philippines

jeambebrendal@su.edu.ph

Gereo A. Patrimonio

IT Officer II, MIS Office

Zamboanga del Norte Provincial Government, Philippines

gereoapatrimonio@su.edu.ph

\title{
"I AM OFFLINE": MEASURING BARRIERS TO OPEN ONLINE LEARNING IN THE PHILIPPINES
}

\begin{abstract}
Open online learning provides new opportunities for students and teachers. However, research shows that completion rates in open online courses are typically low. This paper presents an empirical analysis of the degree of the barriers to open online learning. The respondents are teachers at the tertiary level in the Philippines who experienced a full distance online learning. Responses from 44 respondents were included in the analysis using an adapted survey questionnaire. The study reveals that Internet cost and access and technical problems are substantial barriers to open online learning while social interaction is somewhat of a barrier. It is concluded that infrastructure and technical accessibility are the priority considerations in online learning.
\end{abstract}

Keywords: online learning; ICT in Education; open online learning.

\section{INTRODUCTION}

The problem setting. Online learning is a very broad concept that is somewhat hard to define. Some prefer to distinguish the variations by describing online learning as "wholly" online learning (Oblinger\&Oblinger, 2005), whereas others simply reference the technology medium or context with which it is used (Lowenthal, Wilson, \& Parrish, 2009). Others display direct relationships between previously described modes and online learning by stating that one uses the technology utilized in the other (Rekkedal et al., 2003; Volery\& Lord, 2000). Online learning is described by most authors as access to learning experiences via the use ofany technology (Benson, 2002; Carliner, 2004; Conrad, 2002). On the other hand, both Benson (2002) and Conrad (2002) identify online learning as a more recent version of distance learning which improves access to educational opportunities for learners described as both non-traditional and disenfranchised. Other authors discuss not only the accessibility of online learning, but also its connectivity, flexibility and ability to promote varied interactions (Ally, 2004; Hiltz\&Turoff, 2005; Oblinger\&Oblinger, 2005).

Conversely, online learning can be used to refer to a broadrange of programs that use the Internet to provide instructional materials and facilitate interactions between teachers and 
students and in some cases among students as well. Online learning can be fully online, with all instruction taking place through the Internet, or online elements can be combined with face-toface interactions in what is known as blended learning (Horn and Staker 2010). Nevertheless, the term online learning can be summarized and outlined in two words, "knowledge" and "technology". Further, the NCA Higher Learning Commission (Keairns, 2003) definition of distance education as:

"For the purposes of accreditation review, Distance Education is defined as a formal educational process in which the majority of the instruction occurs when student and instructor are not in the same place. Instruction may be synchronous or asynchronous. Distance education may employ correspondence study, audio, video, or computer technologies."

Analysis of recent studies and publications. There are much enthusiasm and optimism regarding open online learning; however, there are significant barriers that learners still encounterin attempting to succeed in online courses. "Impediments to online teaching and learning can be situational, epistemological, philosophical, psychological, pedagogical, technical, social, and/or cultural" (Berge, 1998). Lloyd, Byrne \& McCoy (2012) found interpersonal barriers, institutional barriers, training and technology barriers, and cost/benefits analysis are factors in the perceived barriers to online learning.

Globally, retention rates in online learning are low. Topdegreeonline.org asserts that in general, the retention rates for online courses have been calculated to be 10 to $20 \%$ lower than the retention rates for the face-to-face learning. In the same manner, the US News and World Report announced that the average retention rate among first-time part-time students is $39 \%$ (Burnsed, October 22, 2010). According to an article by Rob Jenkins in the Chronicle of Higher Education, cited by Luzer (March 16, 2012), "students were more likely to fail or withdraw from online courses than from face-to-face courses regardless of their initial level of preparation".Koller, $\mathrm{Ng}$, Do and Chen (June 3, 2013) assert "retention in massive open online courses (MOOC) should be viewed in the appropriate context, the apparently low retention in MOOCs is often reasonable". They strongly recommended that there must be a consideration in the context of thelearner intent. They revealed

"In 2012, the typical Courseraenrolled between 40,000 and 60,000 students, of whom 50 to $60 \%$ returned for the first lecture. In classes with required programming or peer-graded assignments, around 15 to $20 \%$ of lecture-watchers submitted an assignment for grading. Of this group, approximately $45 \%$ successfully completed the course and earned a Statement of Accomplishment. In total, roughly 5\% of students who signed up for a Coursera MOOC earned a credential signifying official completion of the course."

The article's goal. The study aimed to identify the barriers and challenges to online learning among teachers in higher education institutions. Specifically, this paper presents the degree of online learning barriers as experienced by the respondents. Barriers included in the study include administrative/instructor issues, social interactions, academic skills, technical skills, learner motivation, time and support for studies, cost and access to the Internet, and technical problems. 


\section{THE THEORETICAL BACKGROUNDS}

Distance education has a history that spans almost two centuries (Spector, Merrill, Merrienboer, \& Driscoll, 2008), and this period represents significant changes in how learning occurs and is communicated. Early distance education courses employed first and second Generation communication technologies. First generation in years the 1850s to 1960, was predominately one technology and consisted of print, radio, and television. As new media emerged, such as radio and television, these new technologies were integrated into distance education delivery methods.Meanwhile, in years 1960-1985, second-generation distance learning courses utilized multiple technologies without computers. The media used to deliver distance educationinthe second generation was through audiocassettes, television, videocassettes, fax, and print (Keairns, 2003). As a proof of this, scientists at the University of Illinois created a classroom system based on linked computer terminals. Their students were able to access informational resources while listening to a professor whose lectures were brought in remotely, via some form of television or audio device. Certainly not a form of "online learning" that stands up to the web learning of today, but it was the beginning of enhanced distance learning and the utilization of computer resources for educational purposes (Ann Smarty).

The establishment of the British Open University(1969) marked a significant development in the delivery of distance education by offering a mixed-media approach to distance learning technologies. Learning materials (text, audio \& visuals) were sent to students by mail and supplemented by broadcast radio and television (Matthews, 1999 cited by Keairns, 2003). Multiple technologies including computers and computer networking make up the third generation in the years 1985 to 1995. According to the American InterContinental University (AIU), in the mid-1990s, software developers created programs such as WebCT, Mallard, and Pioneer to make course information more accessible to students. However, the technology of the time proved insufficient and often hampered instructional efforts.

Fourth generation technologies, the current generation, combines previous media but also incorporates high-bandwidth computer technologies including: desktop videoconferencing, twoway interactive real-time audio and video, web-based media, etc. were the types of distance education was Cyber Education, Online Education, Virtual Education, Technology-supported Education, Hybrid Education, Distributed Learning, E-learning, Web-based Education (Keairns, 2003).Each new generation of distance learning technologies increases opportunities for studentto-student and faculty-to-student contact and collaboration (Sherron and Boettcher, 1997).

Although there has been a long history of distance education, the creation of online education occurred just over a decade and a half ago - a relatively short time in academic terms. Early course delivery via the web had started by 1994, soon followed by a more structured approach using the new category of course management systems(Graziadei, et al.).According to the Online Education in the United States (2011), since that time, online education has slowly but steadily grown in popularity to the point that in the fall of 2010, almost one-third of U.S. postsecondary students were taking at least one course online.

People sometimes often interchange online learning with the terms e-learning, Web-based training, computer-based training, computer-based instruction, and technology-based instruction. However, according to Carliner (2014), each of theseis a form of online learning and each term has a particular meaning, but some terms are synonymous. See table 1 for the summary. 


\section{Online Learning Terminologies}

\begin{tabular}{|c|l|}
\hline Online learning & $\begin{array}{l}\text { in its broadest form refers to all types of learning that takes place via } \\
\text { computer. }\end{array}$ \\
\hline E-learning & $\begin{array}{l}\text { is often used to refer to online learning, but learning expert Marc Rosenberg } \\
\text { contends that it is only e-learning if the computer is connected either to the } \\
\text { Internet or to an intranet or extranet (private forms of the Internet that limit } \\
\text { access to authorized users). Because learning materials are available through } \\
\text { the Internet, they can be linked to resources outside the learning program, } \\
\text { such as references, electronic mail, and discussions. Because they do not } \\
\text { require that the computer be connected to the Internet, learning programs on } \\
\text { CD and DVD are technically not forms of e-learning, although they are } \\
\text { forms of online learning. }\end{array}$ \\
\hline $\begin{array}{c}\text { Web-based } \\
\text { Training }\end{array}$ & $\begin{array}{l}\text { is a synonym for e-learning. } \\
\begin{array}{c}\text { Training (also } \\
\text { called computer- } \\
\text { based }\end{array}\end{array}$ \\
$\begin{array}{c}\text { instruction) } \\
\text { refers to courses presented on a computer. The course does not provide links } \\
\text { to learning resources outside of the course. Often, learners take a computer- } \\
\text { based training course on a computer that is not connected to a network. }\end{array}$ \\
$\begin{array}{c}\text { Technology- } \\
\text { based Instruction }\end{array}$ & $\begin{array}{l}\text { has a broader meaning; it refers to learning through any medium other than } \\
\text { the classroom. This includes computers, but also refers to television, } \\
\text { audiotape, videotape, and print. }\end{array}$ \\
\hline
\end{tabular}

According the U.S Department of Education (2012), online learning can be delivered in two different approaches. It can be fully online or blended with face-to-face interactions or also commonly called as hybridapproach. Fully online learningis a form of distance education in which all instruction and assessment are carried out using online, Internet-based delivery (Picciano and Seaman 2009; U.S. Department of Education 2007). In this brief, both teacher-led instruction and resources designed to instruct without the presence of a teacher meet the definition of fully online learning if they include instructional environments accessed exclusively through the Internet.

On the other hand, hybrid approachallows students to receive significant portions of instruction through both face-to-face and online means. Researchers see blended learning in the middle of the spectrum between fully face-to-face and fully online instruction (Graham, Allen, and Ure 2005; U.S. Department of Education 2007; Watson et al. 2010 cited by U.S. Department of Education 2012).

Meanwhile, there are three technologies that support online learning (Carliner, 2004). First, "technologies for managing online programs" and as defined by Carliner it is primarily software. This type of technology performs the tasks of a registrar. It enrolls learners in courses (not just online courses, but also classroom courses), tracks their progress through courses (such as "attendance," and progress on tests and other assessments), records completions, and sends notification of completions and certifications to other systems, and provides reports on learning. The second one is "technologies for developing learning programs". The hardware and software 
technology can help you create the learning materials, prepare them for "publication," and exchange materials with other learning programs. The standards you might have heard about primarily affect the technology for developing and managing online learning programs.Moreover, the last one is "technologies for delivering the learning program". These technologies include the computer hardware (most often a PC) and the software installed on it (such as the operating system that controls the computer) that lets learners uses the learning materials. These technologies can also include specialized hardware and software for playing video and audio and for handling complex interactions between the student and the computer, the cables and software that connect the computers in a network, the protocols and standards or "smarts" that help computers accurately read information transmitted on the network, as well as specialized software such as database programs.

According to the study of Sife, A. S. Lwoga, E. T. and Sanga, C., (2007), functionally, elearning includes a wide variety of learning strategies and ICT applications for exchanging information and gaining knowledge. Such ICT applications include television and radio; Compact Discs (CDs) and Digital Versatile Discs (DVDs); video conferencing; mobile technologies; web-based technologies; and electronic learning platforms.

\section{RESEARCH METHODS}

The study implemented a descriptive and utilized a survey method. The study was conducted in the higher education institutions (HEIs) in the Philippines offering teacher education. Teacher education refers to degree programs in Education such as Bachelor of Science in Secondary Education and Bachelor of Science in Elementary Education offered in public and private HEIs. Respondents are 44 teacher educators who experienced at least one online learning class or training course. Ten is coming from Bohol, 2 from Cavite, 10 from Cebu, 1 from Cotabato, 6 from Manila, 1 from Negros Occidental, 8 from Negros Oriental and 1 from Zamboanga del Norte. There are 27 female respondents and 17 male respondents.

The instrument used in data gathering to accomplish the specific objectives of the study was a survey questionnaire which was adapted from Muilenburg \& Berge (2005). Respondents were asked to rate each barrier identified by Muilenburg\& Berge (2005) according to the fivepoint Likert scale choices: 1 -not a barrier (it is not a barrier to online learning), 2 - somewhat of a barrier(it is not a barrier to online learning), 3 - a barrier(26-50\% barrier to online learning), 4 a strong barrier (51-75\% barrier to online learning) and 5 - a very strong barrier(76-100\% barrier to online learning). The survey administration process was done online using Google Form. The survey administration was done on February 1- March 30, 2014. The statistical tool employed in the data processing is the weighted mean for measuring the competency level.

\section{THE RESULTS AND DISCUSSION}

Of the so many classifications of the impediments, let us look at the results of this study, which used a survey questionnaire that was adapted from Muilenburg \& Berge (2005).

The factor "administrative and instructor issues" is defined by Muilenburg \& Berge (2005) as "barriers that administrators and instructors control," like late delivery of course materials, lack of sufficient academic advisors online, and lack of timely feedback from the instructor.With the 11-item administrative/instructor issues, the overall rating, as can be seen in table2, has a 
mean of 3.02. This is equivalent to "a barrier" standing or consideration. It implies that administration and instructors are not competent enough in handling online learning facility. Nine items are all considered "a barrier," implying that administration and instructors are not competent,with the exceptionof "insufficient training to use the delivery system, "which is perceived as "a strong barrier" (weighted mean, 3.14), and "class size is not right for online learning," which is perceived as "somewhat of a barrier" (weighted mean, 2.48). This perceived "strong barrier" for "insufficient training to use the delivery system" implies that administration and instructors are very incompetent, whereas the "somewhat of a barrier" perception of "class size is not right for online learning" implies competence in the part of the administration and the instructors of online learning.

Dabaj (2011) had the same interpretation of administrative issues. In the study, these issues were related to cost, course availability, obtaining course materials, and administrative support."Allen and Seaman (2007) also pointed out that in their previous studies, academic leaders (which of course includes administrators and instructors of online learning) have consistently commented that faculty often devalue online learning and that it takes "more time and effort to teach an online course." and demotivated faculty and devaluing of online learning by faculty may be partly the cause of some if not many of the administrative/instructor issues of online learning.

Table 2.

\section{Administrative/Instructor Issues}

\begin{tabular}{|l|c|c|}
\hline \multicolumn{1}{|c|}{ Issues } & $\begin{array}{c}\text { Weighted } \\
\text { Mean }\end{array}$ & Description \\
\hline $\begin{array}{l}\text { Lack of sufficient academic advisors in the online training } \\
\text { course }\end{array}$ & 3.07 & A barrier \\
\hline Training course materials are not always delivered on time & 2.89 & A barrier \\
\hline Instructors do not know how to teach online & 3.16 & A barrier \\
\hline Lack of clear expectations/instructions & 3.11 & A barrier \\
\hline Difficulty contacting academic or administrative staff & 2.89 & A barrier \\
\hline Lack of timely feedback from the instructor & 2.80 & A barrier \\
\hline Lack of access to an expert in online learning & 3.32 & A barrier \\
\hline Lack of support services such as tutors & 3.07 & A barrier \\
\hline Lower quality materials/instruction online & 3.05 & A barrier \\
\hline Insufficient training to use the delivery system & 3.41 & A strong barrier \\
\hline Class size is not right for online learning & 2.48 & $\begin{array}{c}\text { Somewhat of a } \\
\text { barrier }\end{array}$ \\
\hline \multicolumn{1}{|c|}{ Overall Mean } & $\mathbf{3 . 0 2}$ & A barrier \\
\hline
\end{tabular}

Table 3 lists items about social interaction issues of online learning. According to Muilenburg \& Berge (2005), social interaction refers to the "learning environment that is created for learning online." The environment should be friendly and social, and one in which learning is promoted, promoting "human relationships, developing group cohesiveness, maintaining the group as a unit, and in other ways helping participants to work together for a mutual cause."Some 
students have trouble with online courses because they prefer to study in a social environment rather than individually.

"Social interactions" factor gets an overall mean of 2.53 and is perceived "somewhat of a barrier."The result implies that users of the online learning system feel somewhat isolated. The item with the highest weighted mean value is "lack of interaction/communication among colearners" (weighted mean, 2.86), which is perceived as "a barrier." This score implies isolation. As for the lowest in social interaction, "online learning seems impersonal" has a weighted mean of 2.20 and is perceived "somewhat of a barrier."The result implies that users are somewhat isolated. The same implication (somewhat isolated) is true for all other items with a perceived "somewhat of a barrier", whereas "a barrier" items implies isolation.In this study, "social interactions" factor ranks as the "least severe barrier" (overall mean, 2.53) of the eight factors, although this ranking is very opposite to Muilenburg \& Berge (2005) results because this factor ranks first or is the most severe barrier $(\bar{x}=2.36)$ : "the single most important barrier to students learning online was a lack of social interaction."The study further discusses that social interaction is strongly related to enjoyment in online learning, effectiveness of learning online, and the possibility of taking another online course. Therefore, improving online learning social interaction would lead to a more effective and enjoyable educational experience.Song et al (2004) also found that participants of the study who were not that satisfied with online learning as compared with traditional classroom learning felt that a lack of community (71\%) within the online environment was a challenge.

Table 3.

Social Interactions

\begin{tabular}{|l|c|c|}
\hline \multicolumn{1}{|c|}{ Issues } & $\begin{array}{c}\text { Weighted } \\
\text { Mean }\end{array}$ & Description \\
\hline $\begin{array}{l}\text { Lack of interaction/communication among co- } \\
\text { learners }\end{array}$ & 2.86 & A barrier \\
\hline Online learning seems impersonal & 2.20 & Somewhat of a barrier \\
\hline Afraid my feelings are isolated & 2.32 & Somewhat of a barrier \\
\hline Lack of social context cues & 2.52 & Somewhat of a barrier \\
\hline Lack of co-learner/trainee collaboration & 2.80 & A barrier \\
\hline Prefer to learn in person & 2.45 & Somewhat of a barrier \\
\hline \multicolumn{1}{|c|}{ Overall Mean } & $\mathbf{2 . 5 3}$ & $\begin{array}{c}\text { Somewhat of a } \\
\text { barrier }\end{array}$ \\
\hline
\end{tabular}

"Academic skills" factor refers to research respondents' perceived barriers to online learning due to their lack of academic skills in areas like writing, reading, or communication (Muilenburg \& Berge, 2005). All six items for academic skills(table 3) are perceived as "a barrier," with an overall mean of 2.67.This score implies lack of academic skills for online learning. Academic skills needed are language, writing, reading, communication, typing, and confidence, as enumerated in the items. "Lack language skills for online learning" scores the highest $(\bar{x}=2.75)$, whereas both "lack communication skills for online learning" and "shy or lack of confidence in online learning" score the lowest ( $\bar{x}=2.61)$. In Muilenburg \& Berge (2005), the academic skills factor was the least severe barrier of the eight $(\bar{x}=1.22)$ compared with this study where it ranks third in the last (overall mean, 2.67). 


\section{Academic Skills}

\begin{tabular}{|c|c|c|}
\hline Issues & $\begin{array}{c}\text { Weighted } \\
\text { Mean }\end{array}$ & Description \\
\hline Lack language skills for online learning & 2.75 & A barrier \\
\hline Lack writing skills for online learning & 2.70 & A barrier \\
\hline Lack reading skills for online learning & 2.68 & A barrier \\
\hline Lack communication skills for online learning & 2.61 & A barrier \\
\hline Lack typing skills for online learning & 2.64 & A barrier \\
\hline Shy or lack of confidence in online learning & 2.61 & A barrier \\
\hline Overall Mean & 2.67 & A barrier \\
\hline
\end{tabular}

Perceived barriers to online learning of the respondents due to their lack of technical skills like"fearing new tools for online learning, lack of software skills, or their unfamiliarity with online learning technical tools" are the "technical skills" factor (Muilenburg \& Berge, 2005).Technical skills (table5) overall mean is 3.11 (perceived to be "a barrier" as well), which also implies the lack of technical skills for online learning. All items are perceived to be "a barrier." Highest is "unfamiliar with online learning technical tools" ( $\bar{x}=3.39)$ and lowest "fear computers and technology" ( $\bar{x}=2.75)$.Items for technical skills include the following: fear of new tools $(\bar{x}=3.0)$, fear of computers and technology $(\bar{x}=2.75)$, lack of online learning software skills $(\bar{x}=3.20)$, lack skills for using the delivery system $(\bar{x}=3.30)$, unfamiliar with online learning technical tools $(\bar{x}=3.39)$, and fear of different learning methods used $(\bar{x}=3.0)$.In Muilenburg \& Berge (2005), technical skill was ranked second to the last least severe barrier $(\bar{x}=1.30)$, whereas in this study, this ranks second most severe barrier (overall mean, 3.11).

Table 5.

Technical Skills

\begin{tabular}{|l|c|c|}
\hline \multicolumn{1}{|c|}{ Issues } & $\begin{array}{c}\text { Weighted } \\
\text { Mean }\end{array}$ & Description \\
\hline Fear new tools for online learning & 3.00 & A barrier \\
\hline Fear computers and technology & 2.75 & A barrier \\
\hline Lack online learning software skills & 3.20 & A barrier \\
\hline Lack skills for using the delivery system & 3.30 & A barrier \\
\hline Unfamiliar with online learning technical tools. & 3.39 & A barrier \\
\hline Fear different learning methods used for online learning. & 3.00 & A barrier \\
\hline \multicolumn{1}{|c|}{ Overall Mean } & $\mathbf{3 . 1 1}$ & A barrier \\
\hline
\end{tabular}

Table 6 is about learner motivation. This is the desire of teacher educators to use online learning,or as defined by Muilenburg \& Berge (2005), teacher educators' characteristics that would affect motivation in online courses such as whether they "procrastinate, choose easier aspects of an assignment to complete, or feel the online learning environment is not inherently motivating."'There are fivefactors considered.Overall mean is 2.78 , perceived by teacher educator respondents as "a barrier."This implies that learners are unmotivated to use open online learning. 
The highest rating is "lack personal motivation for online learning" (3.14). Personal motivation or internal motivation is the driving force of our behavior (Sullo, 2007). Sullo (2007) puts it this way - "internal control psychology is based on the belief that people are internally, not externally, motivated." Further, two items are rated the lowest $(\bar{x}=2.50)$ and are perceived as "somewhat of a barrier": "choose easier, less demanding aspects of assignments," and "online learning environment is not inherently motivating." The perception of "somewhat of a barrier" equally implies a somewhat unmotivated status in the use of open online learning.

Table 6.

\section{Learner Motivation}

\begin{tabular}{|c|c|c|}
\hline Issues & $\begin{array}{l}\text { Weighted } \\
\text { Mean }\end{array}$ & Description \\
\hline Procrastinate, cannot get started & 3.09 & A barrier \\
\hline Lack personal motivation for online learning & 3.14 & A barrier \\
\hline Must take on more responsibility for learning & 2.68 & A barrier \\
\hline Choose easier, less demanding aspects of assignments & 2.50 & Somewhat of a barrier \\
\hline $\begin{array}{l}\text { The online learning environment is not inherently } \\
\text { motivating }\end{array}$ & 2.50 & Somewhat of a barrier \\
\hline Overall Mean & 2.78 & A barrier \\
\hline
\end{tabular}

Time and support for studies are fundamental factors as well."This factor concerns the respondents' perspectives on whether a lack of time or support from family, friends, or people in the workplace causes barriers to their online learning" (Muilenburg \& Berge, 2005).In table 7, "insufficient time to learn during online training courses" has a weighted mean of 3.16, which is perceived as "a barrier" and the highest rating of the five items. This implies a limited time for learning.The lowest is "lack of support from family, friends, and employer," which scored a 2.23 weighted mean ("somewhat of a barrier") and implies that family, friends, and employer are somewhat unsupportive of open online learning. Overall mean for time and support of studies is 2.61. This is perceived as "a barrier" and impliesunsupported online learning.

Table 7.

\section{Time and Support for Studies}

\begin{tabular}{|l|c|c|}
\hline \multicolumn{1}{|c|}{ Issues } & $\begin{array}{c}\text { Weighted } \\
\text { Mean }\end{array}$ & \multicolumn{1}{|c|}{ Description } \\
\hline Fear family life will be disrupted & 2.25 & Somewhat of a barrier \\
\hline Online learning cuts into my personal time & 2.57 & Somewhat of a barrier \\
\hline Lack of support from family, friends, and employer & 2.23 & Somewhat of a barrier \\
\hline Significant interruptions duringmy study at home/work & 2.84 & A barrier \\
\hline Insufficient time to learn during online training courses & 3.16 & A barrier \\
\hline Overall Mean & $\mathbf{2 . 6 1}$ & A barrier \\
\hline
\end{tabular}

Table 7 is about cost and access to the Internet, which concerns whether the respondents "find access to the Internet too expensive, fear the loss of privacy, confidence, or property rights, 
or otherwise find access to the Internet limited to the point of raising barriers to them" (Muilenburg \& Berge, 2005). Three items were asked to teacher educators. Overall mean for cost and access to the Internet is 3.68, which means "a strong barrier." This implies that the Internet is very inaccessible. Two items are perceived to be "a strong barrier," whereas one item is perceived to be "a barrier." The highest weighted meanamong the three is "lack of adequate Internet access" ( $\bar{x}=4.05)$, followed by "needed technology is not available" ( $\bar{x}=3.75)$, andthe lowest is "online learning technology costs too much" $(\bar{x}=3.25)$. Of the eight factors, the "cost and access to the Internet" factor has the highest overall mean $(\bar{x}=3.68)$. This is equivalent to a "most severe barrier" ranking in Muilenburg \& Berge (2005). Cost and access to the Internet only ranked sixth in the study model. In the book by Allen and Seaman (2007), which is the fifth annual report on online learning in US higher education, another conclusion is given relating to cost and access to the Internet issue: "higher costs for online development and delivery are seen as barriers among those who are planning online offerings, but not among those who have online offerings."

Table 8 .

Cost and Access to the Internet

\begin{tabular}{|l|c|c|}
\hline \multicolumn{1}{|c|}{ Issues } & $\begin{array}{c}\text { Weighted } \\
\text { Mean }\end{array}$ & Description \\
\hline Lack adequate Internet access & 4.05 & A strong barrier \\
\hline Online learning technology costs too much & 3.25 & A barrier \\
\hline Needed technology is not available Over-all Mean & 3.75 & A strong barrier \\
\hline \multicolumn{2}{|c|}{$\mathbf{3 . 6 8}$} & A strong barrier \\
\hline
\end{tabular}

Technical problem is a factor about the "lack of consistent platforms, browsers, and software, or the lack of technical assistance that causes obstacles to online learning" (Muilenburg \& Berge 2005). Table 9 (technical problems) has three items as well. All three are perceived "a strong barrier." "Lack technical assistance" is rated the highest, with a weighted mean of 3.57. Second is "incompatibility creates technical problems" ( $\bar{x}=3.50)$. Rated least is "lack of consistent platforms, browsers, and software" (3.43). Song et al (2004) found technical problems as one of three challenges in online learning experiences. Fifty percent $(50 \%)$ of the study participants indicated technical problems as a barrier. This was the biggest challenge reported by study participants (58\%): a challenge to participants who were more satisfied with online learning $(75 \%)$, and those that were equally satisfied with online learning $(54 \%)$ as compared with traditional classroom learning.

Table 9.

\section{Technical Problems}

\begin{tabular}{|l|c|c|}
\hline \multicolumn{1}{|c|}{ Issues } & $\begin{array}{c}\text { Weighted } \\
\text { Mean }\end{array}$ & Description \\
\hline Lack of consistent platforms, browsers, and software & 3.43 & A strong barrier \\
\hline Incompatibility creates technical problems & 3.50 & A strong barrier \\
\hline Lack technical assistance & 3.57 & A strong barrier \\
\hline \multicolumn{1}{|c|}{ Overall Mean } & $\mathbf{3 . 5 0}$ & A strong barrier \\
\hline
\end{tabular}




\section{Summary of Results}

\begin{tabular}{|c|c|c|}
\hline Issues & $\begin{array}{c}\text { Weighted } \\
\text { Mean }\end{array}$ & Description \\
\hline Cost and Access to the Internet & 3.68 & A strong barrier \\
\hline Technical Problems & 3.50 & A strong barrier \\
\hline Technical Skills & 3.11 & A barrier \\
\hline Administrative/Instructor Issues & 3.02 & A barrier \\
\hline Learner Motivation & 2.78 & A barrier \\
\hline Academic Skills & 2.67 & A barrier \\
\hline Time and Support for Studies & 2.61 & A barrier \\
\hline Social Interactions & 2.53 & $\begin{array}{c}\text { Somewhat of a } \\
\text { barrier }\end{array}$ \\
\hline Mean of Means & 2.99 & A barrier \\
\hline
\end{tabular}

The summary of results (table10) shows the ranking from most severe barrier to least severe barrier as perceived by the respondents. The most severe barrier is the issue of cost and access to the Internet (overall mean, 3.68 - a strong barrier), and the least severe barrier is the issue of social interactions (overall mean, 2.53 - somewhat of a barrier). The study reveals that aside from the issue of the cost and access to the Internet, technical problems issue ranks second high barrier to open online learning, with a weighted mean of 3.50. To note, in Muilenburg \& Berge (2005), cost and access to the Internet ranked only sixth, whereas social interactions issue ranked first or most severe barrier. Both became of opposite poles to the results in this study. The overall mean of the eight barriers considered for this study is 2.99 - a barrier. Furthermore, administrative or instructor issues, academic skills, technical skills, learner motivation, and time and support for studies are barriers to online learning.

\section{CONCLUSIONS AND PROSPECTS FOR FURTHER RESEARCH}

There is a need to invest in infrastructure and internet bandwidth. Similarly, there is a need to increase awareness about online learning among teachers in higher education institutions. Teachers must take advantage of the many massive open online courses (MOOCs) available. Moreover, qualified and trained online facilitators and technical support must be formed before any online learning.

\section{REFERENCES}

1. Allen, I.E., Seaman, J. (2007). Online Nation: Five Years of Growth in Online Learning. Needham, MA: SloanConsortium.

2. Ally, M. (2004). Foundations of educational theory for online learning. In Terry (Ed.), The theory and practice of online learning (pp. 3-31). (2nd ed). Athabasca, AB: Athabasca University. Retrieved from http://desarrollo.uces.edu.ar:8180/dspace/ bitstream/123456789/586/1/Theory\%20and\%20Practice\%20of\%20online\%20learning.pdf\#page=227 
3. American InterContinental University (AIU).(2008) ÒHistory of Online Education.Ó 2008. Retrieved from:http://www.aiuonline.edu/online-education/online-education-history.aspx

4. Anderson, P. (2007) "What is Web 2.0? Ideas, technologies and implications for education.JISC Technology and Standards Watch". Retrieved http://www.jisc.ac.uk/media/documents/techwatch/tsw0701b.pdf

5. Benson, A. (2002). Using online learning to meet workforce demand: A case study of stakeholder influence. Quarterly Review of Distance Education, 3(4), 443-452.

6. Berge, Z.L. (1998). "Barriers To Online Teaching In Post-Secondary Institutions: Can Policy Changes Fix It?" Online Journal of Distance Learning Administration, I(2). State University of West Georgia, Distance Education Center.

7. Carliner, S. (2004). An overview of online learning (2nd ed.). Armherst, MA: Human Resource Development Press.

8. Chen N.-S., Kinshuk, Ko H.-C. and Lin T. (2004) "Synchronous Learning Model over the Internet". In Kinshuk, Looi C.-K., Sutinen E., Sampson D., Aedo I., Uden L. and Kähkönen E. (Eds.), Proceedings of the 4th IEEE International Conference on Advanced learning Technologies August 30 - Sept 1, 2004, Joensuu, Finland, Los Alamitos, CA: IEEE Computer Society. pp. 505-509. Retrieved from: http://infosys.massey.ac.nz/ kinshuk/papers/icalt2004_synchronous_model.pdf

9. Conrad, D. (2002). Deep in the hearts of learners: Insights into the nature of online community. Journal of Distance Education, 17(1), 1-19.

10. Dabaj, F. (2011). Analysis of Communication Barriers to Distance Education: A Review Study. Online Journal of Communication and Media Technologies, 1(1)

11. David Brooks, "The Campus Tsunami," New York Times. (2012). Retrieved from: http://uconnhealth2020.uchc.edu/knowledgebase/pdfs/leadership/campus_tsunami.pdf

12. Department for Education and Skill (2004) "Use of interactive whiteboards in history". Retrieved from:http://publications.teachernet.gov.uk/eOrderingDownload/DfES-0812-2004_History.pdf

13. Going the Distance: Online Education in the United States.(2011) (formerly known as the Sloan Online Survey).Retrieved from: http://www.onlinelearningsurvey.com/highered.html.

14. Graziadei, W. D., et al., "Building Asynchronous and Synchronous Teaching-Learning Environments: Exploring a Course/Classroom Management System Solution," Horizon. Retrieved from: http://horizon.unc.edu/projects/monograph/CD/Technological_Tools/ Graziadei.html.

15. Horn, M., and H. Staker. 2011. The rise of K-12 blended learning. InnoSight Institute. Retrieved from: http://www.innosightinstitute.org/innosight/wp-content/uploads/ 2011/01/The-Rise-of-K-12-Blended Learning.pdf.

16. Hunsinger, J. (2005) "How to determine your readiness for mobile e-learning.Information policy". Retrieved from: http://i-policy.typepad.com/informationpolicy/2005/04/how_to_determin.html

17. Keairns, K. (2003) History of Distance http://mysite.du.edu/ kkeairns/de/Text/Lessons/Lesson1.pdf

18. Lowenthal, P., Wilson, B. G., \& Parrish, P. (2009). Context matters: A description and typology of the online learning landscape. AECT International Convention, Louisville, KY.Presented at the 2009 AECT International Convention, Louisville, KY.

19. Muilenburg, L. Y., \& Berge, Z. L. (2005). Student Barriers to Online Learning: A factor analytic study. Distance Education 26(1), 29-48

20. Oblinger, D. G., \&Oblinger, J. L. (2005). Educating the Net Generation.EDUCAUSE. Transforming Education Through Information $\quad$ Technologies. from.http://net.educause.edu/ir/library/pdf/pub7101.pdf

21. Rekkedal, T., Qvist-Eriksen, S., Keegan, D., Súilleabháin, G.Ó., Coughlan, R., Fritsch, H., et al. (2003). Internet based e-learning, pedagogy and support systems. Norway: NKI Distance Education.

22. Smarty, A. (2014) History of Online Education. Retrieved from:http://www.saycampuslife.com/2010/06/18/history-of-online-education/

23. Sherron, Gene T. and Boettcher, Judith V. "Distance Learning: The Shift to Interactivity." CAUSE Professional Paper Series, \#17, 1997. 1-32.

24. Sife, A. S. Lwoga, E. T. and Sanga, C., (2007). New technologies for teaching and learning: Challenges for higher learning institutions in developing countries. International Journal of Education and Development using Information and Communication Technology, 3(2), 57-67.

25. Song, L., Singleton, E.S., Hill, J.R., Koh, M.H.(2004). Improving online learning: Student perceptions of useful and challenging characteristics. Internet and Higher Education 7:59-70 
26. Spector, J. M., Merrill, M. D., Merrienboer, J. V., \& Driscoll, M. P. (2008). Handbook of research on educational communications and technology (3rd ed.). New York, London: Lawrence Erlbaum Associates.

27. Sullo, B. (2007). Activating the Desire to Learn. Alexandria, Virginia: Association for Supervision and Curriculum Development.

28. Turoff, M., Hiltz, S.R., Li, Z., Wang, Y., Cho, H., and Yao, X. (2003).Online collaborative learning enhancement through the Delphi Method.Turkish Online Journal of Distance Education-TOJDE, 7 (2). Retrieved from: http://tojde.anadolu.edu.tr/tojde22/pdf/article_6.pdf

29. U.S. Department of Education, Office of Innovation and Improvement. (2007). Connecting students to advanced courses online: Innovations in education. Washington, DC: Author.

30. U.S. Department of Education, Office of Innovation and Improvement. (2012). Understanding the Implications of Online Learning for Educational Productivity. 2.

31. Volery, T., \& Lord, D. (2000). Critical success factors in online education. International Journal of Educational Management, 14(5), 216-223.

Text of the article was accepted by Editorial Team 15.01.2015.

\title{
"Я ПОЗА ІНТЕРНЕТОМ": ВИМІРЮЮЧИ ПЕРЕШКОДИ ДЛЯ ОНЛАЙН НАВЧАННЯ НА ФІЛІППІНАХ
}

\section{Дейв І. Марціал}

виконуючий обов’ язки декана, Коледж комп'ютерних досліджень

Університет Сіліман, Філіппіни

demarcial@su.edu.ph

Рей Денніс Б. Кабальєро

адміністратор Кібербібліотеки

Університет Сіліман, Філіппіни

reybcaballero@su.edu.ph

\section{Джімбе Б. Рендал}

аспірант, магістр з інформаційних систем

Університет Сіліман, Філіппіни

jeambebrendal@su.edu.ph

\section{Джерео А. Патрімоніо}

IT співробітник

Офіс Інформаційної системи менеджменту, Північна Замбоанга, Філіппіни

gereoapatrimonio@su.edu.ph

\begin{abstract}
Анотація. Відкрите онлайн навчання надає нові можливості для студентів і викладачів. Тим не менш, дослідження показує, що процент студентів, які закінчили онлайн курси досить низький. Ця стаття представляє емпіричний аналіз ступеня бар'єрів для того, щоб започаткувати онлайннавчання. Респондентами виступили вчителі системи вищої освіти на Філіппінах, які пройшли повний курс дистанційного навчання. Аналіз включає відповіді 44 респондентів на запитання підготовленої для дослідження анкети. Результати дослідження показують, що значними перешкодами для започаткування онлайн-навчання $\epsilon$ вартість і доступ до мережі Інтернет, технічні проблеми пов' язані з цим, окрім того, певним барєром є соціальна взаємодія. Зроблено
\end{abstract}


висновки, що інфраструктура та доступність з технічної точки зору є пріоритетними для розвитку онлайн-навчання.

Ключові слова: онлайн навчання; ІКТ в освіті; відкрите онлайн навчання.

\title{
"Я ВНЕ ИНТЕРНЕТА": ИЗМЕРЯЯ ПРЕПЯТСТВИЯ ДЛЯ ОНЛАЙН ОБУЧЕНИЯ НА ФИЛИППИНАХ
}

\author{
Дэйв И. Марциал \\ исполняющий обязанности декана, Колледж компьютерных исследований \\ Университет Силиман, Филиппины \\ demarcial@su.edu.ph \\ Рэй Деннис Б. Кабальеро \\ администратор Кибербиблиотеки \\ Университет Силиман, Филиппины \\ reybcaballero@su.edu.ph \\ Джимбо Б. Рэндал \\ аспирант, магистр информационных систем \\ Университет Силиман, Филиппины \\ jeambebrendal@su.edu.ph

\section{Джерео А. Патримонио} \\ ИТ сотрудник \\ Офис Информационной системы менеджмента, Северная Замбоанга, Филиппины \\ gereoapatrimonio@su.edu.ph
}

\begin{abstract}
Аннотация. Открытое онлайн обучение предоставляет новые возможности для студентов и преподавателей. Тем не менее, исследование показывает, что процент студентов, которые закончили онлайн курсы достаточно низкий. Эта статья представляет эмпирический анализ степени барьеров для того, чтобы открыть онлайн-обучения. Респондентами выступили учителя системы высшего образования на Филиппинах, которые прошли полный курс дистанционного обучения. Анализ включает ответы 44 респондентов на вопросы подготовленной для исследования анкеты. Результаты исследования показывают, что значительные препятствия для онлайн-обучения является стоимость и доступ к сети Интернет, технические проблемы, связанные с этим, кроме того, определенным барьером является социальное взаимодействие. Сделаны выводы, что инфраструктура и доступность, с технической точки зрения, являются приоритетными для развития онлайн-обучения.
\end{abstract}

Ключевые слова: онлайн обучение; ИКТ в образовании; открытое онлайн обучение. 